Portland State University

PDXScholar

2013

\title{
Beyond "Rockhood" - Stigma, Diversity, and Renewal in a Suburban Portland Neighborhood
}

\author{
Alison Hébert \\ Portland State University
}

Follow this and additional works at: https://pdxscholar.library.pdx.edu/honorstheses

Let us know how access to this document benefits you.

\section{Recommended Citation}

Hébert, Alison, "Beyond "Rockhood" - Stigma, Diversity, and Renewal in a Suburban Portland Neighborhood" (2013). University Honors Theses. Paper 18.

https://doi.org/10.15760/honors.21

This Thesis is brought to you for free and open access. It has been accepted for inclusion in University Honors Theses by an authorized administrator of PDXScholar. Please contact us if we can make this document more accessible: pdxscholar@pdx.edu. 
Beyond "Rockhood" - Stigma, Diversity, and Renewal in a Suburban Portland Neighborhood

by

\begin{abstract}
Alison Hébert
An undergraduate honors thesis submitted in partial fulfillment of the requirements for the degree of

Bachelor of Arts

in

University Honors

and

Social Science
\end{abstract}

Thesis Adviser

Matthew Carlson

Portland State University

2013

1| P a g e 


\section{Table of Contents}

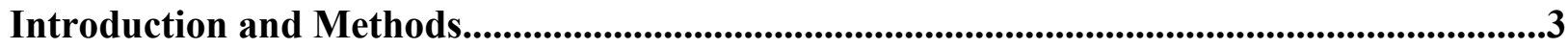

History: Portland, Residential Segregation, and Gentrification...........................................5

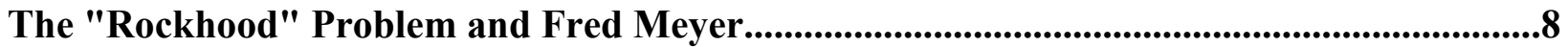

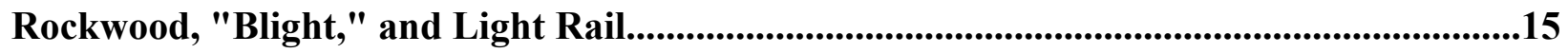

Rockwood Demographics: Diversity and Density........................................................19

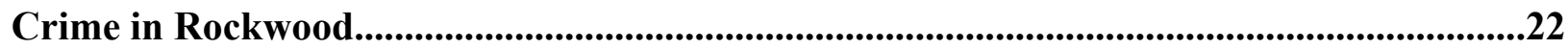

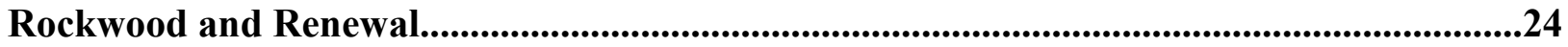

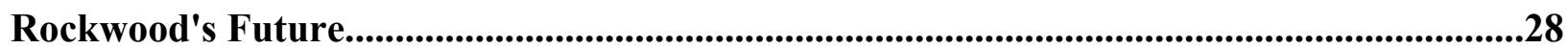

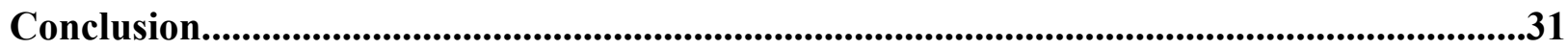

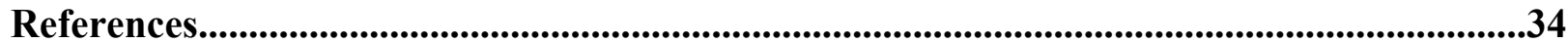


"Ask anyone in East County to describe Rockwood and you're likely to hear them say 'slum', 'trouble', or simply 'stay away.' ... Crime-infested, and poverty-stricken. Today Rockwood is fighting for its very survival."

-Wilkes East Neighborhood Association website.

"When Rockwood was separated into two cities it was on the outer edge of both cities and didn't receive the attention that the rest of these cities received. When Rockwood was incorporated, neither city took a proactive approach to welcome the residents, plan for infrastructure and work on livability issues. It was like a forgotten appendage and did not receive equal capital funds for improvements etc. ... Neither 'old' Gresham residents nor 'old' Portland residents have been willing to accept Rockwood as being part of their city, and [the neighborhood] has always been negatively portrayed by both areas."

-Dina DiNucci, activist and owner, Park Place Coffee, Rockwood.

In 2002, the Fred Meyer grocery store in the heart of Gresham, Oregon's Rockwood neighborhood, closed its doors. The common perception of the reason for the store closure can be stated by most people who live in East County: crime. People see Rockwood, sometimes colloquially referred to as "Rockhood" by locals, as simply an urban blight, just as the quote above describes it. For reasons that defy logic and facts, the Rockwood neighborhood carries a heavy stigma. The closing of the Fred Meyer store more than ten years ago remains the major event people point to as exemplifying the "problem" of Rockwood. When I myself moved to the neighborhood in early 2010, many of my friends and peers reacted with a sort of shock and horror that I would move to such a neighborhood. A coworker provided me with a tale of how his father once lived in Rockwood, but that the crime had gotten too bad, and he told me, flatly, that "at some point, you'll get mugged by a four-foot tall Mexican with a switchblade and then you'll get what I'm saying." The naked bigotry in the statement took me aback.

Well, it has been more than three years (as of this writing) of living in Rockwood, and I have yet to meet with any personal violence or crime, or really come close to it. What I have observed as a resident of the neighborhood was multiple instances of racial profiling by police 
and a police presence (many of the police can often be spotted wearing jackets that read "GANG UNIT") that might make one think that this small, suburban Gresham, Oregon neighborhood is more like South Central Los Angeles. Now, eleven years after the closing of the Rockwood Fred Meyer, the former site sits empty, a temporary park built in its place while the city of Gresham, now owners of the land, have still not come to a decision with regards to what should permanently stand in the old grocery store's place. How did it come to this? Why has Rockwood's bad reputation persisted? What does Rockwood's reputation say about the Portland metro area as a whole? This inquiry seeks to answer the question of "why?" Rockwood has struggled throughout recent years, and, unsurprisingly given Oregon's racial history, the answer lies in a general fear of racial diversity. After examining the history and data, this study comes to the conclusion that the gentrification that affected Portland's Albina neighborhood and then North Portland, is pushing people further outward, out of the city proper and into the suburbs, into neighborhoods like Rockwood, who have now planned and launched urban renewal projects in an effort to repair the neighborhood's image. Whether that will lead to displacement of the minorities and poor within Rockwood itself remains to be seen.

Portland is often considered to be the "whitest" major city in the United States, and 2010 census data indicates that the city proper has gotten even whiter, while surrounding areas, including suburban neighborhoods like Rockwood in Gresham, have gotten significantly more diverse (Hannah-Jones, 2011). Gentrification has pushed minorities and the poor out of the city and into the suburbs, and the suburbs have reacted with fear. This study explores the history of Portland gentrification and how it led to increasing diversity in Portland's suburbs, and how a population of a historically very white city and state reacted to changes in demographics. Additionally, this inquiry examines the racially-motivated stigmatization of this neighborhood 
that straddles the border between Portland and its major eastern suburb, and whether any of that stigma is truly deserved, or if it is merely a result of latent racism. This will be done by studying Rockwood's recent history and Gresham's demographic/crime data . Finally, this inquiry will contemplate the future for Rockwood as it continues to be a community in the throes of change.

\section{Methodology}

In gathering the data for this inquiry, I have interviewed activists and local neighborhood apartment managers. Additionally, I have examined the Census data from 1990-2010 for the Census tracts that make up the Rockwood neighborhood, with an eye on population density and race. This paper also examines the media coverage on the Rockwood neighborhood, with a close reading of the language used to describe the neighborhood and how such language contributes to the stigmatization of Rockwood. Finally, I have incorporated work from other scholars who have studied Portland neighborhoods and race, as well as scholars who have examined the effects of light rail and neighborhood reputation.

\section{History: Portland, Residential Segregation, and Gentrification}

To understand the reasons suburban neighborhoods like Rockwood have increased in racial diversity (and therefore become stigmatized), one must first understand the racial history of Portland, particularly as it relates to residential populations. Karen J. Gibson, an urban planner at Portland State University who has written extensively on gentrification in the Portland metro area, traces the history and causes of gentrification in her article, "Bleeding Albina: A History of Community Disinvestment, 1940-2000." Gibson describes the sudden and sharp gentrification that hit Portland in the 1990s as a result of both a booming population and a city 
that works very hard to perfectly plan development. Historically, people of color in Portland were restricted to specific neighborhoods: Albina for black people, Chinatown for Asians (both areas are in the same part of downtown Portland-- near Union Station and the ports of the Willamette River, where the labor was in the WWII period). Gibson notes that agreements among local real estate agents ensured that minorities were kept restricted to these neighborhoods, noting that even when black Portlanders could afford to buy a home outside of Albina, they were not permitted to do so by real estate agents sworn to preserve property values. Selling a house in a white neighborhood to a black family would have adversely affected neighborhood property values, and was considered an irresponsible act. Furthermore, mortgage lending policies prevented most residents within the Albina neighborhood from owning their own homes, leaving a neighborhood of renters vulnerable to the full press of gentrification (Gibson, 2007). When a neighborhood fills with properties owned by absentee landlords, residents have few options to fight displacement, and owners have little incentive to improve the conditions of tenants; their incentive lies in potential for greater profit.

And so it was that Albina's population was displaced, pushed further into the outer parts of the city, a push that has continued while Portland's population has increased. Karen Gibson, in an article for the Oregonian after the results of the 2010 census, stated rather succinctly on the changing demographics of Portland: "Those who can afford it push out those who can't" (Hannah-Jones 2011). Segregation and redlining created whole groups of people vulnerable to displacement, and gentrification reinforces that vulnerability. Gibson's research suggests that not only do renewal projects lead to gentrification, but also that property owners and other actors in the real estate market allow older buildings to fall to disrepair, in order to spur urban renewal 
projects that can give the neighborhood a makeover, a makeover that increases property values and pushes out residents who can no longer afford to live there (Gibson 2007).

Indeed, if one goes further into the history of racial politics in the state of Oregon, it becomes increasingly apparent why the Portland is considered to be such a white major metro area. Gibson points to the Oregon Donation Land Act of 1850, which offered free pieces of land to settlers, but only if they were white, and the 1857 exclusion clause in the Oregon constitution that criminalized the presence of black people altogether, a clause which remained in place until 1926. In addition, Oregon refused to ratify the 15 th Amendment, which granted citizenship to black Americans and suffrage to black men (Gibson 2007, from McLagan 1980). Gibson also points to the Portland Realty Board's decision in 1919 to adopt the rule banning sale of property in a white neighborhood to a black or Asian person, and the allocation of the Albina district as the only zone within the city that would suffer the loss of property values they associated with having nonwhite residents (Gibson 2007).

During the 1940s war period, when work was abundant and labor was short, the black population of Portland increased by 394\% (Gibson 2007, from Taylor 1998) and many of these newcomers settled in Vanport, until it was destroyed by a massive flood n 1948 destroyed the city, and black residents were forced to cram further into Albina. White flight followed immediately, and by the end of the 1950s, 23,000 whites had left Albina. Portland's black and Asian population were increasingly ghettoized (Gibson 2007).

While residents of Albina sought to build a community regardless of the difficult situation, urban renewal projects, starting in the 1950 s, resulted in a sort of clearing of the neighborhood, giving the government power to declare neighborhoods "blighted" and granting license to clear buildings and redevelop. Some locals resisted and asked for improvements, not a 
clearing of the neighborhood, but, unsurprisingly, they were unsuccessful (Gibson 2007). This trend seems to be par for the course in stories of gentrification, and in Portland, a city known for its aggressive and innovative urban planning, not at all surprising. Gibson's research features a quote from an Albina resident, Lisa Manning: "It used to be that living 'far out' was 15th and Fremont. Now it's 185th and Fremont" (Gibson 2007). The neighborhood borders of Rockwood begin at E 162nd Ave. The factors that characterized Albina's move to gentrification: racial diversity, poverty, high amount of rental properties, a stigmatized reputation, and a large city project aimed at renewal. Whether these factors will lead to wide scale gentrification in Rockwood is still up in the air, but the signs are there.

\section{The "Rockhood" Problem and Fred Meyer}

Like other Portland area neighborhoods, Rockwood has its own neighborhood association. When I spoke with Rockwood's neighborhood association president, Catherine Nicewood, and I asked her what was the major thing she'd like to change about Rockwood, she didn't hesitate: she wants the neighborhood to have a better reputation. As we sat and talked in the Park Place Coffee shop on 182nd and Main, it became clear that my perceptions of the neighborhood as one that is unfairly stigmatized is not a unique one. Ms. Nicewood, who moved to the neighborhood in 2006, sees removing the stigma attached to Rockwood as the greatest challenge the neighborhood faces, the key to overcoming some of the other major problems in Rockwood, particularly attracting private businesses interested in development. Her main plan to counter the neighborhood's bad reputation involves being very pro-active in reporting good news in Rockwood to local media sources like the Oregonian, but it's still an uphill climb. 
Ms. Nicewood explained that problems that occur in the area are blamed on Rockwood, even if they are not actual problems within Rockwood. A prime example would be the closing of the Safeway grocery store on 162nd Avenue and Division Street. This store was located well outside the borders of the Rockwood neighborhood, firmly in the middle of the Centennial neighborhood, yet multiple media sources, including the Portland Tribune, referred to the store as the "Rockwood Safeway." A February 27th, 2011 article on the closing was headlined, "Rockwood Safeway Closing March 12." The brief article is as damning in tone as it is thick on speculation and thin on accuracy. It depends entirely on the comments of a random shopper, relaying rumors she heard from an employee who claimed that the store was closing because of rampant shoplifting. The shopper claims she never felt uncomfortable in the Safeway store, but had observed shoplifting in a nearby Rite Aid store, a piece of anecdotal evidence that means little (anyone who has worked in retail can tell you that shoplifting happens in every stores, in every kind of neighborhood) and is quoted as saying, "It just upsets me because the Rockwood Fred Meyer closed because of shoplifting, and now Safeway." The article has no direct quotes from any employees and ends with another quote from the shopper, one clearly intended to perpetuate the meme that Rockwood is a rough, dangerous neighborhood, "I'm afraid Rockwood is turning into a slum" (Wells 2011). The article is striking in its damning tone, especially considering the Safeway in question is not even in the Rockwood neighborhood. 


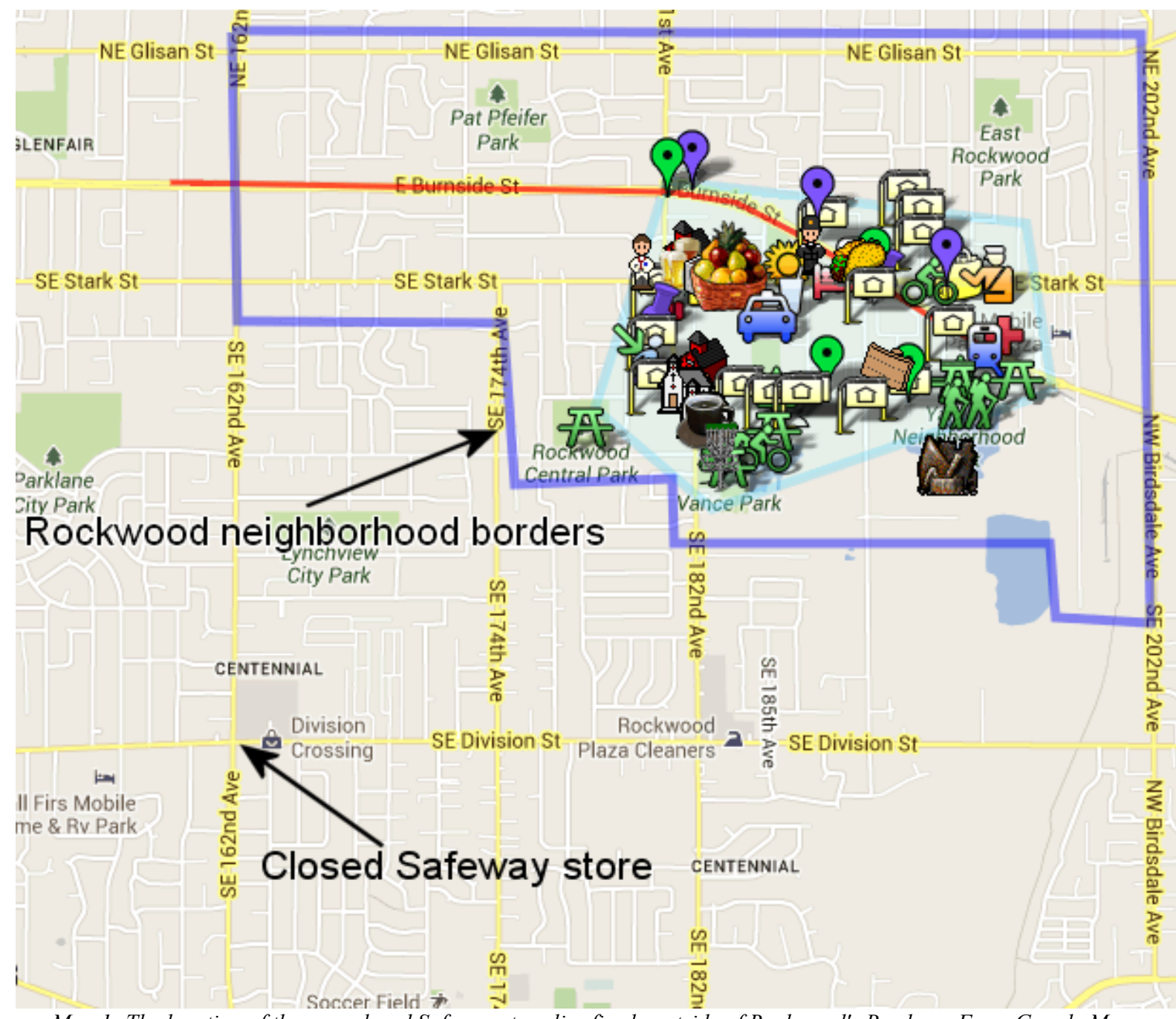

Map 1: The location of the now-closed Safeway store lies firmly outside of Rockwood's Borders. From Google Maps

And what of that Fred Meyer grocery store? The store that closed more than a decade ago in 2002 seems to haunt the Rockwood neighborhood. The lot where the building once stood is empty now, completely undeveloped aside from a small, temporary playground at the edge of the property. Tall grass grows on the giant empty spot in the middle of a densely populated area, in between two very busy streets. On the north side of the vacant lot sits Burnside Street, which runs through the entire city of Portland and is home to the MAX light rail line in Gresham. On the other side is Stark Street, one of the busier thoroughfares in Gresham and Southeast Portland. This space is known as the "Rockwood Triangle" and with the light rail stop right next to it, was 
meant to be a paragon of Portland-style livability: a neighborhood in which most things are available on foot, and public transit will take you anywhere in the city you want.

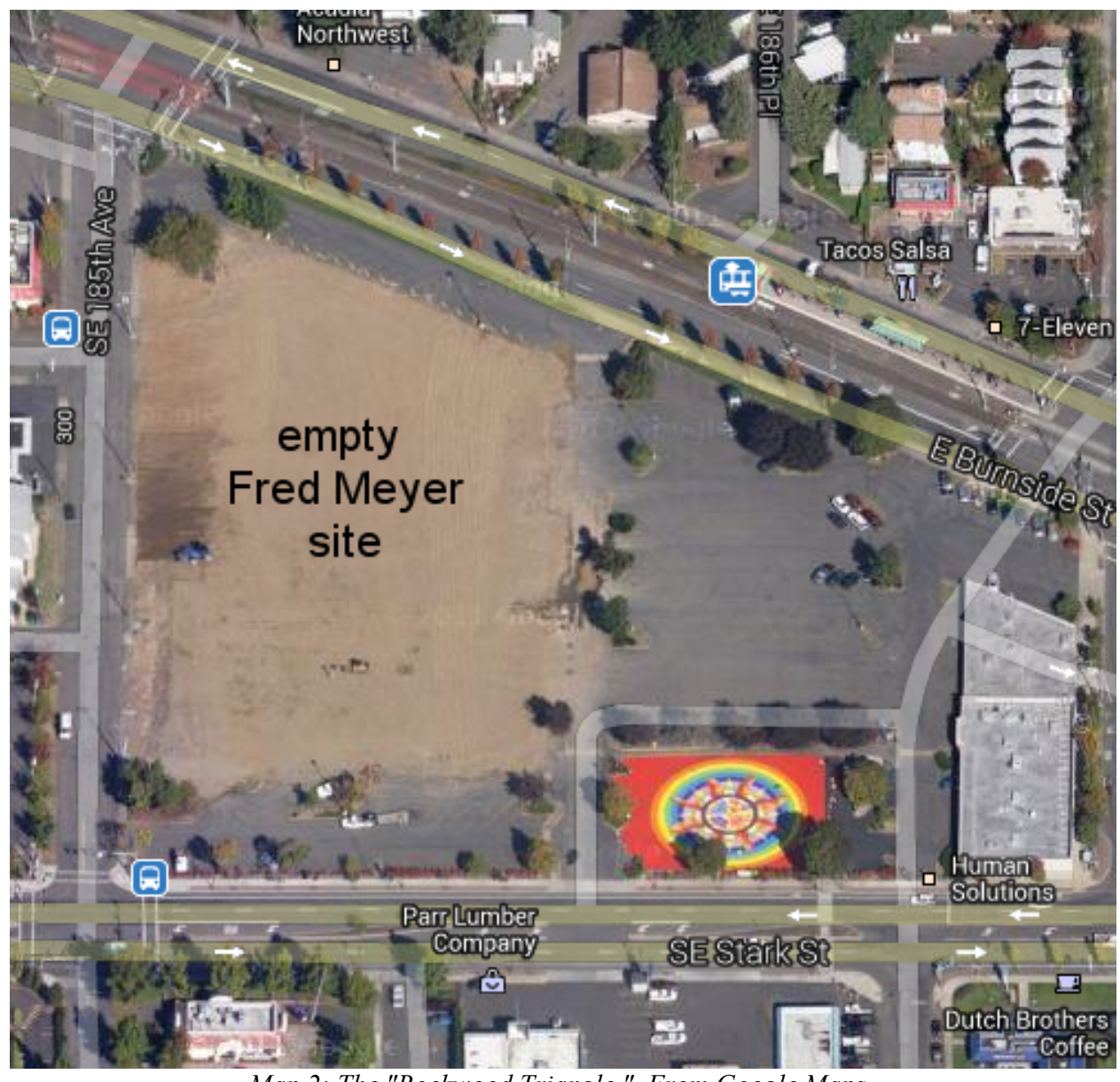

Map 2: The "Rockwood Triangle." From Google Maps.

Local media and Portland area citizens alike tend to blame the Rockwood Fred Meyer's closing on high theft and crime, an assumption taken on faith by most; after all, everyone knows Rockwood is a problem neighborhood, right? Fred Meyer itself doesn't appear to have ever made that assertion, however; in all my research I never came across anything resembling an official statement from Fred Meyer/Kroger that indicated crime was to blame for the Rockwood Fred Meyer store shutdown. All of the news archives included statements from Fred Meyer representatives that more or less state that the store was simply unprofitable, and "in decline for a number of years," as Fred Meyer spokesman Rob Boley put it, hardly a firm assertion that crime 
and shoplifting alone were to blame (Trevison 2002). In fact, some activists within the Rockwood neighborhood believe it to be a very different story.

Dina DiNucci is the owner of Park Place Coffee, a Rockwood neighborhood business. When one walks into the coffee shop on 182nd and Main, it appears to be half coffee shop/café and half neighborhood community center. In addition to selling coffee and food, jewelry and other small items from local artisans sit on display for sale. The largest wall in the shop is one of photos and clippings adorned with the letters "OUR COMMUNITY" spelled out above. Many of the patrons in the café appeared friendly and familiar with the proprietor, and DiNucci herself is more than just a local business owner. She is something of an activist for the Rockwood neighborhood, running a blog about life in the neighborhood and participating in and organizing many community events. Once I arrived in the shop (which, despite living in the neighborhood for more than three years, I'd never stepped into), it became very obvious why Rockwood neighborhood association president Catherine Nicewood asked that our one-on-one conversation be there. DiNucci has lived in Rockwood for longer than Nicewood, long enough to have been one of the activists who fought to save the Rockwood Fred Meyer store.

DiNucci's blog features a passionate article about the Fred Meyer closing, describing a closure motivated more by a desire to shift more business to the corporation's nearby Wood Village store more than any inherent problems in the Rockwood neighborhood. Indeed, in the original Oregonian newspaper article announcing the impending closure, the Fred Meyer representative's vague statement about a store in decline is followed immediately by a statement that the Wood Village Fred Meyer "is in a market that is going to grow," indicating from the beginning a focus on growing the Wood Village store (Trevison 2002). DiNucci elaborates further: 
"The reasoning was challenged back then by many... those in Fred Meyer Corporate who spoke anonymously, and definitely plenty of workers within the store. It was pointed out that the store was not a full service store and that the profits were not as high so the store was planned on being closed for that reason; it was pointed out that none of the security measures that were in place at ALL other Fred Meyer stores were added to the Rockwood site, because the determination had been made to close before and no further capital costs were to be added. For a store with high crime, it was noted that this store implemented none of the crime deterrents added to the other stores, which would of course have had an effect. It was noted that other stores in North Portland had just as high/higher of theft rates. But the reason stated by those 'in the know' was Wood Village Fred Meyer was not getting the traffic they had wanted and WinCo had moved not far down the street. It was determined that by closing the Rockwood location - which was not a high volume store - they may be able to increase sales at Wood Village.

-Dina DiNucci, "How Fred Meyer Screwed Rockwood," September 22nd, 2012

It certainly does seem to benefit Fred Meyer to have allowed the rumor of crime and blight to take the blame for the closure of the Rockwood store. This rumor allows the closure to be Rockwood's fault, and not Fred Meyer's. It turns a story about a crucial business abandoning a vulnerable community into a story of a neighborhood of thugs chasing away a decent business. Another article from the Oregonian in 2002, which discusses how DiNucci organized rallies and letter-writing campaigns to save the local store, describes the impact of the closure on the most vulnerable members of the Rockwood community. The then-apartment manager of the nearby Barberry Village apartment complex mentions that several tenants, particularly the elderly and young mothers without driver's licenses, withdrew from their leases in the complex almost immediately after the store announced the closure (Trevison 2002). As a current resident of Barberry Village, a racially diverse apartment community comprised mostly of families with young children, I have observed many fellow residents utilizing the nearby 7-11 convenience store for groceries, or pulling carts full of groceries from far-away discount grocery store Winco off the MAX trains. In the eleven years since Fred Meyer vacated the Rockwood Triangle, no new major grocery stores have opened in Rockwood. The only remaining grocery store, an 
Albertson's on 181st and Halsey, sits at the very edge of the neighborhood, on a street serviced by a bus line with infrequent service. In this, Rockwood is something of a food desert, particularly for residents who rely solely on public transportation.

When I asked Rockwood neighborhood association president Catherine Nicewood about what the residents want most in the neighborhood, the answer, without hesitation, was a grocery store. She also indicated that residents have specifically requested a Winco grocery store, a chain known in the Portland area as an affordable option, popular among working families. The natural site for such a store would have been on the old Fred Meyer site, conveniently located next to a MAX light rail stop and several apartment complexes. But there have been obstacles to replacing Fred Meyer, which is why the site remains empty, eleven years later. While Fred Meyer announced the store's closing in 2002, the company's lease was set through 2012 (Trevison 2002). According to activist Dina DiNucci, Fred Meyer stalled on subletting the site to anyone else, "They were locked into a lease where most assumed they would sell to the first offer. But Fred Meyer/Kroger drove the stake in deeper by refusing to entertain offers from any business that was similar to theirs. Though the neighborhood needed a grocery store, Fred Meyer turned away any offers from such amenities. Fred Meyer was much more concerned about their competition moving into the neighborhood and potentially affecting their stores in Gresham/Wood Village and 148th and SE Division than doing the responsible thing for the Rockwood community. Behind the scenes, the development staff at the City of Gresham heard new interest of buyers, but could not get Fred Meyer to let their lease go - instead leaving an empty eyesore in the middle of Rockwood " (DiNucci 2012).

Indeed, nothing at all happened with the vacant Fred Meyer site at all for a couple of years. Wal-Mart had an interest in the site, but, in typical Portland fashion as it always seems to 
be with Wal-Mart, there was resistance in the area, this time from a group called GreshamFirst, which aimed to keep Wal-Mart out of anywhere in Gresham. Around this same time, June of 2005, the city of Gresham finally reached a deal with Fred Meyer/Kroger to purchase the site, effectively ending Wal-Mart's plans (Franzen 2005). Just a little more than a month before that, a local developer, Fred Bruning, sought to build a new, vast new mixed-use urban shopping center on the spot; in fact, he had some success with building other vast centers in the Portland metro area (Franzen 2005), like many of the plans people have had for the site, it never came to fruition. Not long after the Fred Meyer closing in January of 2003, the city of Gresham approved a $\$ 92$ million urban renewal plan for Rockwood. The plan was enthusiastically received by the Multnomah County Board of Commissioners. As the "gateway to Gresham" from the city of Portland, it seemed intuitive to invest in the Rockwood neighborhood (Mortenson 2003). And while renewal projects have been underway in the last decade, the empty space where a community's most vital grocery store once still reminds everyone in the neighborhood that there is something very important missing. The lack of a replacement for the demolished store is something neither residents nor city officials wanted, as evidenced by the fact that then-city manager expressed a desire to fill the space quickly even before the closing of the store. In December of 2002, he stated, "They're still a property lessee. ... Hopefully, they could see another use for that facility that would be good for the community" (Trevison 2002). It seems apparent now that these hopes were for naught.

\section{Rockwood, "Blight," and Light Rail}

It's striking how often the word "blight" is used to describe Rockwood. Nearly every news article summons the word, which conjures images of disease, decay, and destruction. 
Some articles are stunning in their casual description of a densely populated neighborhood as a "ghetto" or a "slum" or "infested" with crime. While the neighborhood has certainly faced its challenges, at times the juxtaposition of negative language with descriptions of Rockwood's racial and ethnic diversity is more than a little troubling. An article from 2006 by Robin Franzen of the Oregonian, the Portland area's largest and most respected newspaper, illustrates this juxtaposition perfectly. It begins with an almost clichéd anecdote about a local Rockwood resident who grew up in the city and laments its decline and now won't let her grandson play in the neighborhood. Franzen describes Rockwood as "once a modest working-class neighborhood with its familiar stores and mom and pop restaurants" (Franzen 2006), a curious description for multiple reasons. Firstly, there seems to be an assertion that levels of poverty and "workingclass" are mutually exclusive. By describing Rockwood as "working-class" in past-tense terms, and then going on to point to the high poverty in the neighborhood paints a picture of the poor, and especially Rockwood's poor, as people who do not work. The other curious element of that description is the "familiar stores and mom and pop restaurants" element, since there are, in fact, many "mom and pop" small businesses in Rockwood. Small stores and shops, like Park Place Coffee, or the multiple small shops that cater to Latino customers, dot Rockwood. It is the big chains like Fred Meyer that are missing.

Franzen's article continues on to other the newer residents of Rockwood, tracing the decline of the neighborhood to the arrival of the MAX light rail Blue Line in 1986, which "bore through its neighborhoods of modest single-family homes, bringing strangers and scads of new apartments and adding to Rockwood's stigma of being nowhere. Latinos, Russians and other immigrants arrived, looking for an inexpensive place to stay while figuring out new lives. 
With more people came more crime, hastening an exodus of businesses" (Franzen 2006). The piece captures the idea of white flight in reaction to diversity very well, and though it does include some interesting insights from then-Gresham police chief Carla Piluso on how perceived disorder is greater than actual disorder in Gresham, crediting the amount of crime to the high population density of the neighborhood and stating, "I think it's perception, and perception is a hard thing to combat" (Franzen 2006). It is, indeed.

Work by Sullivan and Bachmeier in 2012 examined the differences in levels of perceived disorder among races in three Portland neighborhoods in the process of gentrification, surveying 571 residents. The study found that white residents perceived more problems in the neighborhoods than black residents (Sullivan and Bachmeier 2012). The Sullivan and Bachmeier study is particularly relevant to this study of Rockwood because it tracks the opinions of neighborhoods that are in the same metro area and have been gentrifying.

Rockwood is definitely not gentrified at this point, and has become one of the most diverse neighborhoods in the Portland metro area, so the Sullivan and Bachmeier study might provide an interesting glimpse into what contributes to Rockwood's bad reputation. Portland has seen rapid gentrification in the inner parts of the city in the last twenty years, pushing the (as mentioned earlier, in relationship to other major United States metro areas, rather small) minority population further outward, leading up to 2010 census findings that show the city of Portland getting whiter and the suburbs becoming increasingly diverse (Hannah-Jones 2011). It follows, perhaps, that the predominantly white residents of nearby neighborhoods might look at Rockwood, with its high minority population, and have a harsher opinion of the neighborhood for that reason alone. 
Light rail, which came to Rockwood in 1986, was supposed to be a boon for Rockwood and Gresham. It was intended to bring some of Portland's famous "livability" to the suburbs. However, in a way it has perhaps hastened gentrification of the city of Portland, providing a way for working poor without cars to live outside the city and still commute to work inside of Portland. With life in neighborhoods like Albina, an historical home to people of color in Portland, becoming increasingly expensive, and multiple apartment complexes near the light rail line in Gresham, it is not surprising that many minorities moved to the suburbs. And with businesses like Fred Meyer moving out of Rockwood, the light rail did not, sadly, bring the expected livability to the neighborhood. The Portland ideal of livability is one which everything a person needs is within walking distance. With Fred Meyer gone and nothing to replace it, Rockwood's livability has been gone for more than ten years now.

It's something of a paradox, as the literature has found that adding light rail to a community typically increases livability and convenience for residents. Brown and Werner's research surveyed residents of a Salt Lake City neighborhood about their perceptions of the neighborhood after before and after a new light rail stop. Their work found that residents expected higher crime, more car traffic, and higher housing costs, but their actual experiences did not measure up to those expectations. What they did find was a greater sense of community, a better neighborhood reputation than expected, more child and pedestrian safety, and no real difference in crime levels (Brown and Werner 2011). Somehow, these results don't seem to coincide with the Rockwood story, a neighborhood which got its light rail in 1986 . The difference of perception of the Rockwood neighborhood perhaps lies in the demographic makeup of the area, as well as the extraordinarily high population density of the neighborhood. The high number of apartment complexes near the transit stops provide opportunities for low-income 
households to live in close proximity to transit into the city. As gentrification drives up rent in Portland, Rockwood is far out enough from the city center to be affordable, and is at least close enough to transit for residents without cars to be able to get to work and to a grocery store, even if both trips make for a long commute. In a way, the distance Rockwood residents must travel for food and for work-- the 2000 Census data indicates that $30-40 \%$ of Rockwood (and most of East County) has a commute to work between 30-39 minutes, a sharp contrast to the relatively low commutes for residents in the city proper (see Map \#3).

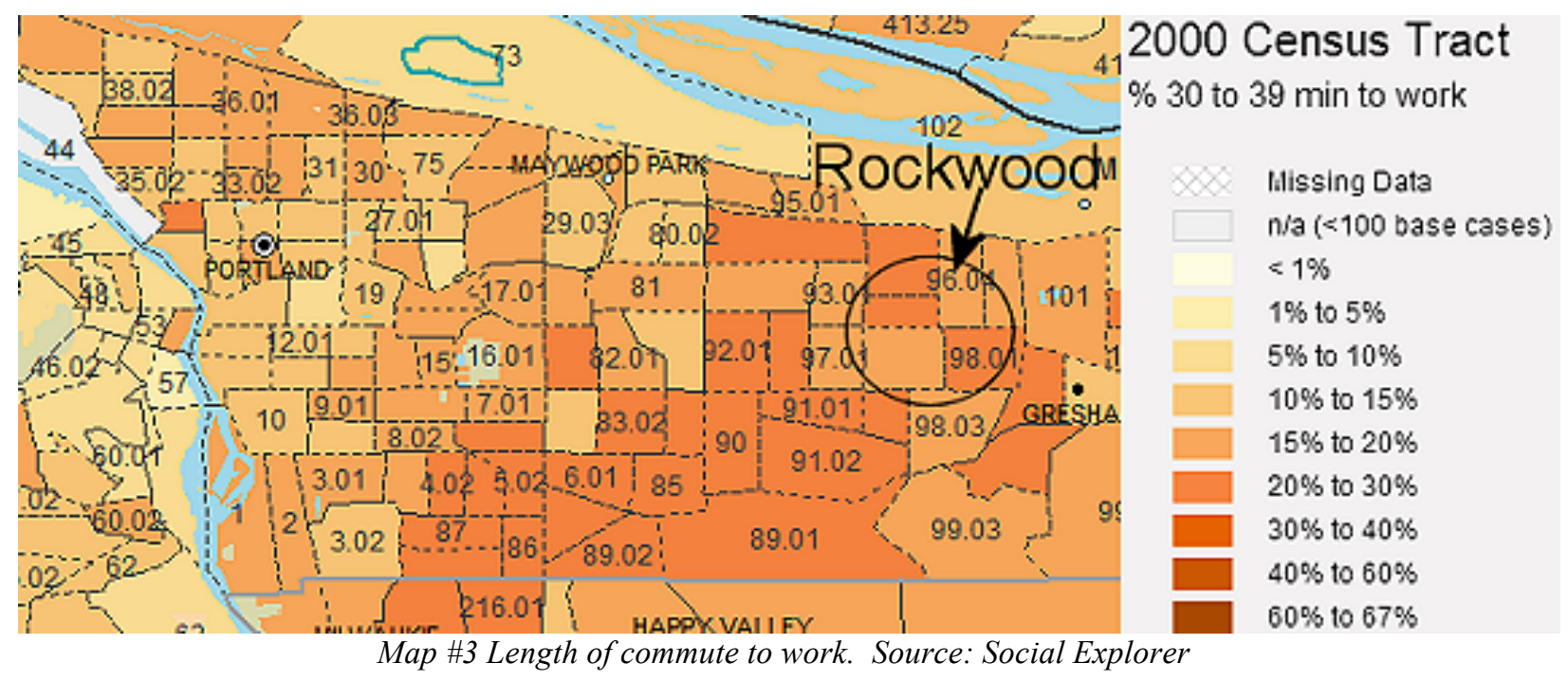

\section{Rockwood Demographics: Diversity and Density}

The Rockwood neighborhood is comprised of parts of six census tracts as of the 2000 and 2010 census, up from four tracts in the 1990 census (covering the same geographic area-- a testament to how quickly this neighborhood has been growing in population. It should be noted that some of these tracts overlap into adjacent neighborhoods, as well). The 1990 census data (Table \#1) shows significantly less racial diversity in the neighborhood; the four tracts that overlapped with Rockwood in 1990 were $91 \%$ white, with only a 4.2\% Hispanic population. 


\begin{tabular}{|l|l|l|l|l|l|}
\hline & Tract 96.01 & Tract 96.02 & Tract 97.02 & Tract 98.01 & Totals \\
\hline Total Pop. & 7,370 & 7,037 & 6,335 & 2,812 & 23,551 \\
\hline White & $6,764(91.8 \%)$ & $6,468(91.9 \%)$ & $5,890(93 \%)$ & $2,297(81.7 \%)$ & $21,419(91 \%)$ \\
\hline Black & $122(1.7 \%)$ & $90(1.3 \%)$ & $63(1 \%)$ & $91(3.2 \%)$ & $366(1.6 \%)$ \\
\hline Native Amer. & $89(1.2 \%)$ & $76(1.1 \%)$ & $62(1 \%)$ & $36(1.3 \%)$ & $263(1.1 \%)$ \\
\hline Asian & $200(2.7 \%)$ & $138(2 \%)$ & $117(1.9 \%)$ & $51(1.8 \%)$ & $506(2.2 \%)$ \\
\hline Other & $3(0 \%)$ & $3(0 \%)$ & $9(0.1 \%)$ & $2(0.1 \%)$ & $17(0.1 \%)$ \\
\hline Hispanic & $192(2.6 \%)$ & $262(3.7 \%)$ & $191(3 \%)$ & $335(11.9 \%)$ & $980(4.2 \%)$ \\
\hline
\end{tabular}

Table 1 - 1990 Census Data for the Tracts that make up the Rockwood Neighborhood. Source: Social Explorer.

The 1990 data is useful as a starting point in understanding the demographic differences in the Rockwood neighborhood over the last twenty-plus years. By the time the 2000 census data was in, Rockwood had gained a new census tract because of a significant increase in population density, and the minority population, in particular the Hispanic population had increased a great deal. It is the density increase that locals tend to "officially" point to as the reason behind the decline of the neighborhood in newspapers and other media articles about the Rockwood neighborhood, but it's hard to imagine the perception of the neighborhood being unaffected by the increasing diversity of the population. Tables 2 and 3 show the significant differences in the same geographic area as the 1990 data, in which the percentage of residents who are white declines while overall population increases, and minority population, particularly the Hispanic population, increases dramatically. 


\begin{tabular}{|c|c|c|c|c|c|c|c|}
\hline & \begin{tabular}{|l|} 
Tract \\
96.03 \\
\end{tabular} & $\begin{array}{l}\text { Tract } \\
96.04 \\
\end{array}$ & \begin{tabular}{|l|} 
Tract \\
96.05 \\
\end{tabular} & $\begin{array}{l}\text { Tract } \\
96.06\end{array}$ & $\begin{array}{l}\text { Tract } \\
97.02 \\
\end{array}$ & $\begin{array}{l}\text { Tract } \\
98.01\end{array}$ & Totals \\
\hline $\begin{array}{l}\text { Total } \\
\text { Pop }\end{array}$ & 3,340 & 4,757 & 4,523 & 4,721 & 7,013 & 4,484 & 28,836 \\
\hline White & $\begin{array}{l}2,746 \\
(82.2 \%)\end{array}$ & $\begin{array}{l}3,117 \\
(65.5 \%)\end{array}$ & $\begin{array}{l}3,397 \\
(75.1 \%)\end{array}$ & $\begin{array}{l}3,024 \\
(64.1 \%)\end{array}$ & $\begin{array}{l}5,176 \\
(73.8 \%)\end{array}$ & $\begin{array}{l}2,316 \\
(51.7 \%)\end{array}$ & $\begin{array}{l}19,776 \\
(68.6 \%)\end{array}$ \\
\hline Black & $73(2.2 \%)$ & $\begin{array}{l}157 \\
(3.3 \%)\end{array}$ & \begin{tabular}{|l|}
136 \\
$(3.0 \%)$
\end{tabular} & $\begin{array}{l}161 \\
(3.4 \%)\end{array}$ & $\begin{array}{l}109 \\
(1.6 \%)\end{array}$ & $\begin{array}{l}139 \\
(3.1 \%)\end{array}$ & $\begin{array}{l}775 \\
(2.7 \%)\end{array}$ \\
\hline $\begin{array}{l}\text { Native } \\
\text { Amer. }\end{array}$ & $24(0.7 \%)$ & $37(0.8 \%)$ & $25(0.6 \%)$ & $44(0.9 \%)$ & $53(0.8 \%)$ & $38(0.9 \%)$ & $\begin{array}{l}221 \\
(0.8 \%)\end{array}$ \\
\hline Asian & $135(4 \%)$ & $92(1.9 \%)$ & $\begin{array}{l}280 \\
(6.2 \%)\end{array}$ & $\begin{array}{l}183 \\
(3.9 \%)\end{array}$ & $\begin{array}{l}316 \\
(4.5 \%)\end{array}$ & $94(2.1 \%)$ & $\begin{array}{l}1,100 \\
(3.8 \%)\end{array}$ \\
\hline $\begin{array}{l}\text { Multiple } \\
\text { races }\end{array}$ & \begin{tabular}{|l|}
110 \\
$(3.3 \%)$
\end{tabular} & $\begin{array}{l}158 \\
(3.3 \%)\end{array}$ & \begin{tabular}{|l|}
128 \\
$(2.8 \%)$
\end{tabular} & $\begin{array}{l}278 \\
(5.9 \%)\end{array}$ & $\begin{array}{l}230 \\
(3.3 \%)\end{array}$ & $177(4 \%)$ & $\begin{array}{l}1,081 \\
(3.8 \%)\end{array}$ \\
\hline Hispanic & $\begin{array}{l}248 \\
(7.4 \%)\end{array}$ & $\begin{array}{l}1,179 \\
(24.8 \%)\end{array}$ & $\begin{array}{l}542 \\
(12 \%)\end{array}$ & $\begin{array}{l}991 \\
(21 \%)\end{array}$ & $\begin{array}{l}1,088 \\
(15.5 \%)\end{array}$ & $\begin{array}{l}1,707 \\
(38.1 \%)\end{array}$ & $\begin{array}{l}5,755 \\
(20 \%)\end{array}$ \\
\hline
\end{tabular}

Table 2 - 2000 Census data for the tracts that make up the Rockwood Neighborhood. Source: Social Explorer

Between 1990 and 2000, population for these tracts increased by 5,285 residents overall, and the Hispanic population increased by 4,775 residents, while the white population decreased by 1,643 . This trend of white flight in the face of an influx of minority residents continued with the 2010 census data.

\begin{tabular}{|c|c|c|c|c|c|c|c|}
\hline & \begin{tabular}{|l|} 
Tract \\
96.03 \\
\end{tabular} & $\begin{array}{l}\text { Tract } \\
96.04 \\
\end{array}$ & \begin{tabular}{|l|} 
Tract \\
96.05 \\
\end{tabular} & $\begin{array}{l}\text { Tract } \\
96.06\end{array}$ & $\begin{array}{l}\text { Tract } \\
97.02 \\
\end{array}$ & $\begin{array}{l}\text { Tract } \\
98.01 \\
\end{array}$ & Totals \\
\hline $\begin{array}{l}\text { Total } \\
\text { Pop }\end{array}$ & 3,752 & 5,013 & 5,569 & 5,251 & 8,199 & 4,546 & 32,346 \\
\hline White & $\begin{array}{l}2,446 \\
(65.2 \%)\end{array}$ & $\begin{array}{l}2,643 \\
(52.7 \%)\end{array}$ & $\begin{array}{l}3,044 \\
(54.7 \%)\end{array}$ & $\begin{array}{l}2,478 \\
(47.2 \%)\end{array}$ & $\begin{array}{l}4,985 \\
(60.8 \%)\end{array}$ & $\begin{array}{l}2,266 \\
(49.7 \%)\end{array}$ & $\begin{array}{l}17,862 \\
(55.2 \%)\end{array}$ \\
\hline Black & $\begin{array}{l}147 \\
(3.9 \%)\end{array}$ & $\begin{array}{l}359 \\
(7.2 \%)\end{array}$ & $500(9 \%)$ & $\begin{array}{l}347 \\
(6.6 \%)\end{array}$ & $\begin{array}{l}262 \\
(3.2 \%)\end{array}$ & $\begin{array}{l}326 \\
(7.2 \%)\end{array}$ & $\begin{array}{l}1,941 \\
(6 \%)\end{array}$ \\
\hline $\begin{array}{l}\text { Native } \\
\text { Amer. }\end{array}$ & $37(1 \%)$ & $37(0.7 \%)$ & $29(0.5 \%)$ & $51(1 \%)$ & $58(0.7 \%)$ & $38(0.8 \%)$ & $\begin{array}{l}250 \\
(0.8 \%)\end{array}$ \\
\hline Asian & $\begin{array}{l}190 \\
(5.1 \%)\end{array}$ & $151(3 \%)$ & $\begin{array}{l}639 \\
(11.5 \%)\end{array}$ & $\begin{array}{l}253 \\
(4.8 \%)\end{array}$ & $\begin{array}{l}496 \\
(6.1 \%)\end{array}$ & $99(2.2 \%)$ & $\begin{array}{l}1,828 \\
(5.7 \%)\end{array}$ \\
\hline $\begin{array}{l}\text { Multiple } \\
\text { Races }\end{array}$ & $\begin{array}{l}105 \\
(2.8 \%)\end{array}$ & $\begin{array}{l}164 \\
(3.3 \%)\end{array}$ & $\begin{array}{l}208 \\
(3.7 \%)\end{array}$ & $\begin{array}{l}201 \\
(3.8 \%)\end{array}$ & $\begin{array}{l}231 \\
(2.8 \%)\end{array}$ & $\begin{array}{l}159 \\
(3.5 \%)\end{array}$ & $\begin{array}{l}1,068 \\
(3.3 \%)\end{array}$ \\
\hline Hispanic & $\begin{array}{l}781 \\
(20.8 \%)\end{array}$ & $\begin{array}{l}1,587 \\
(31.7 \%)\end{array}$ & $\begin{array}{l}1,090 \\
(19.6 \%)\end{array}$ & $\begin{array}{l}1,771 \\
(33.7 \%)\end{array}$ & $\begin{array}{l}2,066 \\
(25.2 \%)\end{array}$ & $\begin{array}{l}1,616 \\
(35.4 \%)\end{array}$ & $\begin{array}{l}8,911 \\
(27.6 \%)\end{array}$ \\
\hline
\end{tabular}

Table 3 - 2010 census data for the tracts that make up the Rockwood Neighborhood. Source: Social Explorer 
Table 3 shows all the same trends: a declining white population, a booming Hispanic population, and an increase in most minority populations in the neighborhood, while overall population in Rockwood continues to grow. Indeed, the data indicates that there are nearly ten thousand more people in Rockwood as of 2010 than in 1990. This is reflected in Table 4, which tracks the overall population density in the Rockwood Census tracts since 1990.

\begin{tabular}{|l|l|l|l|}
\hline & $\mathbf{1 9 9 0}$ Census & 2000 Census & 2010 Census \\
\hline Tract 96.01 & $4,980.0$ & $\mathrm{X}$ & $\mathrm{X}$ \\
\hline Tract 96.02 & $4,621.1$ & $\mathrm{X}$ & $\mathrm{X}$ \\
\hline Tract 96.03 & $\mathrm{X}$ & $4,966.1$ & $5,558.1$ \\
\hline Tract 96.04 & $\mathrm{X}$ & $5,598.6$ & $5,778.1$ \\
\hline Tract 96.05 & $\mathrm{X}$ & $4,503.7$ & $5,441.7$ \\
\hline Tract 96.06 & $\mathrm{X}$ & $9,993.2$ & $11,146.6$ \\
\hline Tract 97.02 & $6,183.9$ & $6,853.0$ & $8,050.7$ \\
\hline Tract 98.01 & $2,764.0$ & $4,404.0$ & $4,734.6$ \\
\hline $\begin{array}{l}\text { Total Density per } \\
\text { square mile }\end{array}$ & $\mathbf{4 , 6 6 9 . 1}$ & $\mathbf{5 , 7 1 7 . 6}$ & $\mathbf{6 , 4 4 4 . 6}$ \\
\hline
\end{tabular}

Table 4 - Population density per square mile in Rockwood Census tracts, 1990-2010. Source: Social Explorer.

This marked rise in density, unfortunately, has been accompanied by a sharp decline in neighborhood resources and amenities, most significantly the Fred Meyer closing leaving one grocery store on the edge of a very highly populated neighborhood. Census tract 96.06 is one of the most densely populated tracts in the entire Portland metro area, with only some of the tracts in the heart of Portland's downtown having higher population density. The main difference, though, is the accessibility resources. Downtown, there are multiple neighborhood amenities within easy walking distance, a full university, and many job opportunities. The Rockwood neighborhood, however, has few amenities within easy walking or public transportation distance. Vance Park sits on the southwest edge of the neighborhood, next to the aforementioned Park Place Coffee which serves as something of a community hangout, but its location on 182nd and an infrequent bus line means it's mainly accessible to those who can drive to it. Because many residents of Rockwood are low income, these resources are not within easy distance. 


\section{Crime in Rockwood}

So, has Rockwood properly earned its reputation as a hotbed of criminal activity and therefore "unsafe?" Table 5 shows the instances of criminal acts within Rockwood during this period of time, in comparison with crimes committed in the entire city of Gresham.

\begin{tabular}{|c|c|c|c|}
\hline Crime & Rockwood & All Gresham & $\%$ in Rockwood \\
\hline Theft & 59 & 357 & $17 \%$ \\
\hline Simple Assault & 86 & 207 & $42 \%$ \\
\hline Drug Laws & 64 & 147 & $44 \%$ \\
\hline Vandalism & 55 & 265 & $21 \%$ \\
\hline Trespassing & 48 & 114 & $42 \%$ \\
\hline Non-injury Accident & 48 & 210 & $23 \%$ \\
\hline Disorderly Conduct & 47 & 130 & $36 \%$ \\
\hline DUII & 41 & 153 & $27 \%$ \\
\hline Burglary & 40 & 196 & $20 \%$ \\
\hline Vehicle Theft & 35 & 166 & $21 \%$ \\
\hline Fraud & 30 & 108 & $28 \%$ \\
\hline Aggravated Assault & 26 & 69 & $38 \%$ \\
\hline Runaway & 17 & 69 & $25 \%$ \\
\hline Injury Accident & 15 & 96 & $16 \%$ \\
\hline Robbery & 15 & 36 & $42 \%$ \\
\hline Underage Drinking & 8 & 22 & $36 \%$ \\
\hline Forgery & 8 & 39 & $21 \%$ \\
\hline Weapons Laws & 8 & 17 & $47 \%$ \\
\hline Sex Crimes (not rape) & 5 & 32 & $16 \%$ \\
\hline Arson & 2 & 8 & $25 \%$ \\
\hline Kidnapping & 2 & 3 & $67 \%$ \\
\hline TOTAL & 659 & 2,444 & $27 \%$ \\
\hline
\end{tabular}

Table 5 - GPD Cases Between March 1 and June 1, 2012. Source: Gresham Neighborhood Association/GPD.

As of the 2010 census, the six census tracts that make up the Rockwood neighborhood account for 32,346 residents. According to the same Census date, the total population of Gresham stands at 105,594 , meaning that the six tracts that comprise the Rockwood neighborhood account for about $30.6 \%$ of the city's population, yet the total incidents of crime in Rockwood as shown in Table 5 account for $27 \%$ of the crime in the city of Gresham. Thus, while certainly there are some troubling pieces of data in the table for the neighborhood, such as 
the accounting for more than forty percent of the robberies and assaults in the city, it doesn't appear as if Rockwood is inordinately dangerous, in comparison with the rest of the city of Gresham, despite the high population density in the neighborhood.

This data coincides with the assertion by many residents, including community activists like Dina DiNucci and Catherine Nicewood, that the reality of Rockwood's "crime problem" doesn't quite live up to the reputation. Yet it has become the easy answer people give when one asks "why?" to Rockwood's problems. Certainly, as mentioned earlier, local media has contributed to the stigmatization of the Rockwood neighborhood, often describing the community as blighted and crime-ridden, without facts or statistics to back up such assertions. After examining the data, it's hard to come to any other conclusion for the construction of this community narrative of Rockwood as an exceptionally dangerous neighborhood than racially motivated prejudices. Gentrification has pushed lower income people to neighborhoods like Rockwood, and after spending three years living in the neighborhood, I have personally witnessed an exaggerated police presence in the neighborhood at all times, which makes one wonder how much of reported crime would Rockwood account for without that heightened police presence? On multiple occasions, I have personally witnessed police giving more attention to minority offenders-- once, at the Rockwood MAX stop, I witnessed an officer stop a white woman who hadn't purchased a MAX ticket, only to immediately let her go once he noticed two black male youths stepping off the train, giving her a warning so he could deal with what was presumably a more "dangerous" target. I have witnessed, on multiple occasions, police sitting in wait by the exit to the large Barberry Village apartment complex across from the very busy 7-11 (a wildly busy convenience store, most likely because there is no nearby grocery store that's an easy walking distance) for residents to cross the 
street without using the crosswalk, eager to hand out jaywalking arrests. After nine years in Portland utilizing the various MAX lines as my exclusive method of transportation, I have been stopped fewer than five times to show proof of fare payment on the train in all of the rest of Portland, but at the Rockwood transit stop specifically, I have been asked to show proof of fare more than twenty times. Police cars are visible all over the neighborhood on a regular basis, and a Gresham Police Department community office sits at the bottom of the Rockwood Triangle, adjacent to the empty Fred Meyer site and the Rockwood MAX line train stop. Given this, it doesn't seem surprising that there are a significant number of arrests in Rockwood, particularly for "trespassing" as the most common charge. And yet, even considering these factors, the data in Table 5 indicates that Rockwood doesn't particularly account for an inordinate amount of crime compared to the rest of the city of Gresham. It's fair to say, then, in my opinion, that Gresham's reputation as "Rockhood" is decidedly unearned.

\section{Renewal in Rockwood}

Recognizing that Rockwood as a community did have needs that were not being met, the city of Gresham approved a massive urban renewal project in February of 2003, just a month after the Fred Meyer closing, declaring Rockwood Gresham's first Urban Renewal Area and allotting \$92 million in funding over a 20 year period ("Rockwood Highlights" 2013). Some of this money was used to buy the empty Fred Meyer site in 2005, beating competing offers from Wal-Mart. However, eight years later, it's hard to see how much this acquisition has actually helped the Rockwood neighborhood. Despite local aversion to a corporate behemoth like WalMart, the location of a store within the Rockwood Triangle--particularly if the store would have been a Supercenter that sold groceries--could possibly have done a great deal in giving 
Rockwood residents access to jobs, food, and other resources within walking distance. Multiple plans to develop the site have come and gone, and as of 2013, there is still no firm plan. The purchase of the site accounted for $\$ 8.1$ million of the $\$ 92$ million allotted for the urban renewal project in Rockwood (Franzen 2005).

While waiting for the Fred Meyer site to be developed into something substantial (a grocery store to replace the defunct one is most desired by the Rockwood Neighborhood Association), a small park has been created on one edge of the property, which the city of Gresham is now calling a "Catalyst Site" for future development. The Plaza del Sol park includes a children's playground, a walking path, and a field of wildflowers, meant only to be an interim use of the valuable site that will not impede future development, but will improve the overall aesthetic of the area and give residents some sort of use out of the property until it is developed ("Catalyst Site" 2013).

In addition, urban renewal funds have been used to increase pedestrian safety in the neighborhood, including a realignment of 187th/188th Ave through the Rockwood Triangle directly to the MAX station, better sidewalks on Burnside Street, general improvements to Stark Street including new medians, bus shelters, and sidewalks, and a completely new MAX line train station at the 188th Ave/Rockwood stop. The stations at this stop were previously staggered for each direction the trains went, but are now in alignment, and have clear shelters on the platforms to increase safety. The new station also includes security cameras and increased lighting, as well as a public art display entitled the "Rockwood Sunrise," by Seattle artist Dan Corson. This $\$ 5.31$ million project, completed in 2011 , was funded jointly by Trimet $(\$ 160,000)$, the Oregon Department of Transportation ( $\$ 3$ million) and the Rockwood urban renewal project ( $\$ 2.15$ 
million), contributing to the urban renewal projects aiming to beautify the area around the Rockwood Triangle and make it more enticing to developers (Webber 2011).

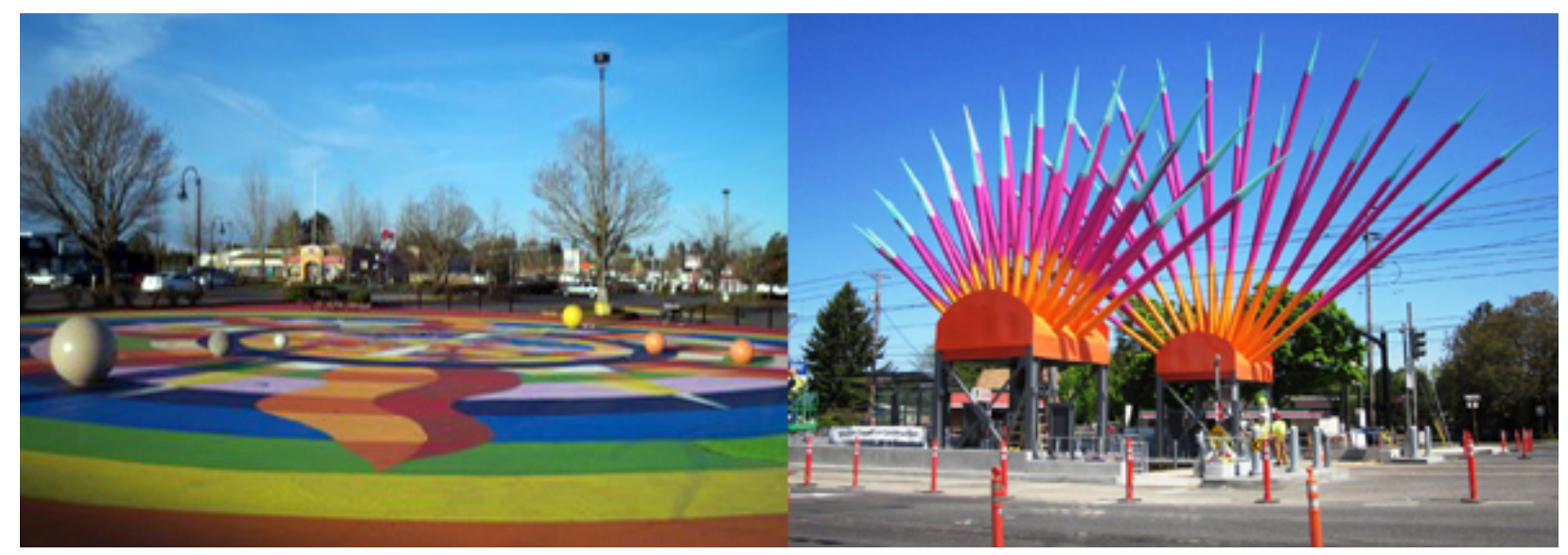

Picture 1 - Left: Plaza del Sol Park. Right: "Rockwood Sunrise" public art at the new 188th Ave stops. Picture Sources: City of Gresham

Another addition to the Rockwood neighborhood in recent years has been the construction of the new East County Courthouse on 185th Ave, which was subsidized not by renewal project dollars, but federal recovery zone bonds (Bjork 2011). Additionally, a new Rockwood Public Safety facility is currently under construction, with a projected completion in December 2013. This two-story facility on 181 st Ave is intended to provide a more visible police presence in the neighborhood (though, as a three-year resident of Rockwood, I can say it's hard to see how the police in the neighborhood could become more visible than they already are) and the City of Gresham's website declares that the new community center will "generate positive activity on the site, and contribute to neighborhood vitality" before going on to say that "the facility will house a range of police functions, including support for patrol officers and other special units and programs serving Rockwood" ("Rockwood Public Safety Facility" 2013). The site presents this as something meant to attract area development, but its effectiveness on that point is unclear, as unclear as the question of whether an even more heightened police presence in the neighborhood will truly make residents, particularly the poor and minority 
residents, feel more comfortable and safe. Certainly new buildings like the courthouse and the police community center may bring some shiny new architecture to Rockwood, and the construction of the buildings will create some work in the neighborhood, but neither is a grocery store. In total, most of the projects of urban renewal seem to be with an eye toward public safety and neighborhood beautification, with little progress made in the way of what Rockwood truly needs: economic development. Current research has indicated that the "new urban renewal" projects of the 1990s and the 2000s parallel the older urban renewal projects from post-World War II to the mid 1970s, in which inner cities were developed at the expense of displacing residents of color, but that the major difference between the urban renewal projects of these two time periods is that race and class were leading factors in residential displacement (Hyra 2012).

\section{Rockwood's Future}

At this moment, it is difficult to say what the future will hold for Rockwood. When speaking to the apartment manager for Barberry Village, the largest apartment complex in the neighborhood, the general impression is that there has been significant improvement in the neighborhood overall in the last couple of years. This assertion was repeated by Catherine Nicewood, who in our discussions indicated that the neighborhood association has been working closely with Rockwood apartment managers, encouraging them to be more stringent in their background checks. With the completion of the new MAX station and the Plaza del Sol park, the area of the Rockwood Triangle has become more aesthetically pleasing if not remarkably more functional. Numerous improvements have been made to the Barberry Village apartments as well as neighboring complexes, with new roofing and siding installed on many units.

However, these improvements have not been free to residents. Rent has risen by nearly a 
hundred dollars in the last three years at Barberry Village, for with the new management and improvements came new expenses. As the Portland metro area continues to grow and housing in the city proper grows with it, it's very possible that Rockwood, a neighborhood that acts as the gateway between Portland and Gresham, could be next in line in Portland's sprawling gentrification. It is also possible that the one thing that would make Rockwood a truly livable neighborhood, a grocery store once again placed in the Rockwood Triangle, would further drive up housing prices in the area. Urban renewal projects have been associated with gentrification within the city of Portland; there is little reason to believe the projects will not cause the same reaction in Rockwood. There is no doubt that Portland's urban poor have already moved outward, seeing declining rates of childhood poverty in the city, only to find that the poverty has moved outward, into the suburbs, the problem not so much solved as it has been redistributed (Butz \& Zuberi 2011). The study by Butz \& Zuberi in 2011 on Portland's urban poverty gathered data from multiple sources to find that home ownership by whites in the Portland metro had risen, and declined for minorities, and that even though Portland's real estate prices are not as high as in other major west coast metro areas, few residents in Portland actually view their neighborhood's affordability to be poor, possibly because rents and home prices have increased more quickly than income in the area (Butz \& Zuberi 2011).

Ultimately, it is the opinion of this writer that the major contributor to the stigmatization of Rockwood is the increasing racial diversity of the neighborhood, diversity within what has traditionally been one of the whitest, if not the whitest, major metro area in the United States. The "decline" of the Rockwood neighborhood as described by multiple newspaper articles and Portland area residents has been within the last twenty years, after the construction of the MAX light rail stop, which Census data tells us perfectly coincides with the increasing minority 
population in the neighborhood. The closing of the Fred Meyer store and the media coverage and rumors that followed contribute to the "moral panic" narrative of the neighborhood: the idea that good, decent hardworking people and businesses were abandoning a neighborhood beyond saving. It's certainly true that businesses have left the neighborhood, as have white residents, but what they were running from appears to be the presence of minority populations. In a paper exploring the "reputational ghettos" of St. Paul's and Bristol in the United Kingdom, Tom Slater and Ntsiki Anderson explore the history of the word "ghetto," tracing its roots to segregation of Jewish citizens during the Renaissance. Since then, the word "ghetto" has always had a component of segregation in its meaning, and an unmistakably negative connotation. However, their findings indicated that segregation was low in these selected neighborhoods, and it's fair to say that segregation is low within the Rockwood neighborhood as well (it might be where many Portland metro area Latinos live, but demographically overall, it is quite diverse relative to many other Portland area neighborhoods), but ultimately, media narratives that emerged in all cases created a lasting impression among area residents (Slater and Anderson 2011).

If gentrification does come to Rockwood after the urban renewal efforts complete, previous research indicates that the remaining (white, middle-class) residents will not be displeased with the changes, as those who remain in gentrifying neighborhoods in the Portland metro area tend to view the changes in the neighborhood more positively (Sullivan 2007). This leaves one to wonder: does anyone with real power care about the fate of Rockwood neighborhood residents? The city's focus on beautification and public safety in current renewal projects for the neighborhood are all measures meant to lead to development, to make the area more enticing to developers, but thus far hasn't attracted the needed development to the area, or 
in some cases, prevented it, as the purchase of the Fred Meyer site when Wal-Mart was interested did.

These efforts offer a distinctly Portland metro area flavor to the projects: the city of Gresham wants Rockwood to have a better reputation, but it also has to have the right kind of reputation, one in which a massive corporate chain like Wal-Mart that has a tendency of rankling west coast liberals does not fit. It is not my intention to argue that Wal-Mart could have been a savior for Rockwood or that its corporate policies are never damaging to a neighborhood, but rather to point out that interested development in the area has been rejected by the city of Gresham, while Rockwood residents wait within their food desert. The existing business in the neighborhood include multiple check-cashing/payday loan establishments, small convenience stores, fast food, and bars, so it's hard to see how Wal-Mart's presence would have made the business environment any worse, but plans that have been proposed (and never came into fruition) for the Fred Meyer site have been more ambitious: mixed-use land proposals to create urban centers of commerce, residence, and education have dazzled the thoughts of the media and the Gresham City Council, all indicating a desire to make Rockwood in Portland's model of urban livability, the same model which created the massive gentrification that led to the changing demographics of the Rockwood neighborhood.

\section{Conclusion}

After examining literature on Portland area gentrification and poverty, as well as literature on the effects and causes of a stigmatized neighborhood reputation, it is the conclusion of this study that Rockwood's status as a "blighted" neighborhood is directly linked to an increase in racial diversity, despite the fact that the neighborhood itself is not particularly 
dangerous or responsible for more than its fare share of criminal activity in the city of Gresham. This follows a history of racial homogeneity, residential segregation, and gentrification within the city of Portland, as well as a larger history of racial homogeneity within the state of Oregon dating back to the mid-19th century.

Despite the efforts of dedicated community activists, some of whom have been fighting for Rockwood's reputation for more than ten years like business owner and activist Dina DiNucci, and despite the investment of the $\$ 92$ million urban renewal funds from the city, Rockwood remains a place with limited resources for residents and long commute times into the city for work and (for residents who rely on public transportation) for groceries. The high and increasing population density within Rockwood highlights the urgency of these issues, as Portland's urban poverty moves suburban. Ultimately, it may well be that Rockwood will recover, but it may happen at the expense of residents who will find themselves displaced. Rockwood's urban renewal projects thus far have not created a marked change in neighborhood diversity (in fact, the Census data clearly shows increasing diversity and density between 2000 and 2010), but it is hard to imagine that the Fred Meyer site in the Rockwood Triangle will remain vacant for another ten years as the other urban renewal projects roll along. It may be that the city has had difficulty finding development for the site because the neighborhood's reputation is persistently stigmatized, or because the city itself has a certain idea of what kind of businesses they want (the mixed-use urban centers that have been proposed and dropped multiple times) and don't want (Wal-Mart).

For their part, activists within the neighborhood have a positive outlook, though this doesn't necessarily follow through with activists of adjacent neighborhoods, as the quote that opens this paper from the Wilkes East Neighborhood Association website clearly indicates (the 
Wilkes Esat Neighborhood Association appears to have a particular grudge against Rockwood-there are several articles on the site with similarly damning language to describe the neighborhood directly adjacent to them). Rockwood Neighborhood Association President Catherin Nicewood points to the work Compassionate Connect has engaged in within the Barberry Village apartments. The Christian organization makes it their mission to move into distressed neighborhoods and attempt to build a sense of community. In Barberry Village, this has manifested in free community dinners and activities on the property, such as classes on bike repair and basic math. Nicewood also points to the work of the Rosewood Initiative, a non-profit organization that caters to an area that includes Rockwood and includes neighborhood and youth outreach and a community center for activities.

Between the work of community organizations, activists, and the city of Gresham, it is clear that there are many in the area eager to solve the "Rockhood" problem. The future of the neighborhood is unclear, but as rapidly as the neighborhood has changed over the last two decades, it seems at this moment impossible to tell when or if the change will end and the neighborhood will become stable and resourceful to residents. Furthermore, it is impossible to say whether any changes or improvements to Rockwood will negatively or positively impact current residents. 


\section{REFERENCES}

Bjork, Nick. "East County Courthouse in Multnomah County groundbreaking scheduled." Daily Journal of Commerce. January 5, 2011.

Brown, Barbara B. and Werner, Carol M. "The Residents' Benefits and Concerns Before and After a New Rail Stop: Do Residents Get What They Expect?" 2011. Environment and Behavior. 43(6) pp. 789-806. DOI: 10.1177/0013816510392030

Butz, Andrew and Zuberi, Daniyal. "Local approaches to counter a wider pattern? Urban poverty in Portland, OR." The Social Science Journal. 2012. 49. 359-367.

City of Gresham website. "Catalyst Site." 2013. http://greshamoregon.gov/city/city-departments/urban-renewal/capitalprojects/template. $\operatorname{aspx} ? \mathrm{id}=5814$

City of Gresham website. "Rockwood Highlights." 2013. http://greshamoregon.gov/city/city-departments/neighborhoods-and-communityengagement/neighborhoodassociations/neighborhood/?HoodID=4224\#/uploadedimages/Internet/City/City_Departments/Ne ighborhoods and Community Engagement/Neighborhood_Associations/Photo_Gallery/202nd Douglas_Fir_Grove.JPG

City of Gresham website. "Rockwood Public Safety Facility." 2013. http://greshamoregon.gov/RPSF/

City of Gresham website. "Rockwood Statistics." Gresham Police Department crime data. 2012. (no longer available online)

City of Gresham website. "Urban Renewal Capital Projects." 2013. http://greshamoregon.gov/city/city-departments/urban-renewal/capitalprojects/template. $\operatorname{aspx} ? \mathrm{id}=4460$

DiNucci, Dina. "How Fred Meyer SCREWED Rockwood." September 22, 2012. Blog post. http://parkplacecoffee.blogspot.com/2012/09/how-fred-meyer-screwed-rockwood.html

DiNucci, Dina. "Rockwood Gets Incorporated. Where IS Rockwood Exactly?" Sepember 29, 2012. Blog post.

http://parkplacecoffee.blogspot.com/2012/09/rockwood-gets-incorporated-where-is.html

Franzen, Robin. "Developer Wants to Give Rockwood a New Urban Core." The Oregonian. April 30, 2005.

Franzen, Robin. "Gresham Opponents On Guard for Other Wal-Mart Plans." The Oregonian. June 29, 2005. 
Franzen, Robin. "The Long Road to Renewal." The Oregonian. March 12, 2006.

Franzen, Robin. "Renewal Board Scores on Rockwood Site Bid." The Oregonian. June 29, 2005.

Gibson, Karen J. "Bleeding Albina: A History of Community Disinvestment, 1940-2000." Transforming Anthropology. 2007. 15(1) 3-25.

Hannah-Jones, Nikole. "In Portland's heart, 2010 Census shows diversity dwindling." The Oregonian. April 30, 2011.

Hyra, Derek S. "Conceptualizing the New Urban Renewal: Comparing the Past to the Present." Urban Affairs Review. 2012. 48(4) 498-527. DOI: 10.1177/1078087411434905

Slater, Tom and Anderson, Ntsiki. "The reputational ghetto: territorial stigmatisation in St. Paul's, Bristol." Transactions of the Institute of British Geographers. 2011 Royal Geographic Society.

Sullivan, Daniel Monroe. "Reassessing Gentrification: Measuring Residents' Opinions Using Survey Data." Urban Affairs Review. 2007. 45:583. DOI: 10.1177/1078087406295828

Sullivan, Daniel Monroe and Bachmeier, James D. "Racial Differences in Perceived Disorder in Three Gentrifying Portland Neighborhoods." Advances in Applied Sociology. 2012. 2(3) 229-236.

Trevison, Catherine. "Customers Ask Locally Run Kroger Subsidiary to Keep Area Store." The Oregonian. December 3, 2002.

Trevison, Catherine. "Gresham, Ore., Hopes to Fill Space Rockwood Grocery Leaves Behind." The Oregonian. December 4, 2002.

Trevison, Catherine. "Portland, Ore., Area to Lose Fred Meyer." The Oregonian. November 25, 2000.

Webber, Angela. "Rockwood MAX station in Gresham complete, to open Friday." Daily Journal of Commerce. May 25, 2011.

Wells, Shannon. "Rockwood Safeway closing March 12." The Portland Tribune. February 27, 2011.

Wilkes East Neighborhood. "UPDATE: Rockwood 10 years later: millions wasted, the former Fred Meyer site remains a vacant lot." June 17, 2009. Neighborhood association blog post. http://www.wilkeseastna.org/node/381 